UDC: 159.92 .9 .07

DOI: https://doi.org/10.24195/2414-4665-2017-7-19

\author{
Oksana Davydova, \\ post-graduate student, University of Education Management, \\ National Academy of Educational Sciences of Ukraine, \\ high level certificate psychologist, \\ Kremenchuk Lyceum of Information Technologies named after N. M. Shevchenko, \\ 3, Oleha Koshovoho Str., Kremenchuk, Ukraine
}

\title{
PSYCHOLOGICAL PECULIARITIES OF TEACHING PROFESSION
}

The paper deals with the analysis of the results of the summative stage of the experiment aimed at examining the peculiarities of teaching profession. The study involved 205 teachers of different educational institutions of Kremenchuh, Poltava region, Ukraine. For studying the peculiarities of teaching profession and revealing the essence of its procedural component according to the parameters associated with professional competence and efficient work there was used Teacher's Psychological Profile Method by H. Rezapkina and Z. Rezapkina. Besides, Personality SocioCommunication Competence Inventory was applied for studying the peculiarities of teaching profession more profoundly according to the operational (activity) criterion. In order to examine the efficiency of the operational (activity) component of teaching activities and to reveal individual differences in teaching activities regulation by teachers there was applied The Teaching Style Efficiency Scale by M. Aminov and N. Shelikhova. Mann-Whitney U test for independent samples was utilized in order to study the gender-and experience-related peculiarities of teachers. According to the research outcomes, there have been distinguished the following psychological peculiarities of teaching profession: a) the motivational component, which implies that teachers' desire to avoid failures and events which cause negative emotions are not their leading motives, most of the pedagogues reflect the level of professional success in terms of satisfaction with work and its conditions, manifest interest in the process and results of professional activities, are satisfied with their own skills, personal qualities and their social role; $b$ ) the emotional and axiological component: most teachers face emotional overloads which are manifested in the instability of their emotional states; $c$ ) the operational (activity) component: most of the respondents possess highly developed communication skills, they are able to cope with problems and challenges, as a rule use democratic teaching style; gender characteristics and work experience determine the change in teachers' didactic communication.

Keywords: teaching profession, teaching methods, structure of teaching, components of teaching, levels of development, characteristics of didactic communication, gender peculiarities.

\section{Introduction}

In modern educational processes the phenomena of uncertainty of the future and informational chaos require a teacher to understand their unstructured essence, inward nature of a human being in general, and a child in particular. Modern teaching involves the nonlinear development of children which also covers possible changes. Concerning the issues of the mechanisms of social transformations not only in the educational system of Ukraine, but also in the society in general, we emphasize a new determination of the educational process under unpredictable, changing, chaotic conditions. Besides, this process depends on the " $3 \mathrm{~d}$ coordinate system": uncertainty, variety and complexity, which requires a teacher understand the necessity of the educational process organization focused not only on ready knowledge and algorithms of tasks solution but on the formation of every student's independency by means of managing his/her independently gained experience.

The teaching profession involves a lot of questions such as how do the teachers manage break their own stereotypes concerning their own responsibility for their students' academic performance? Will be the retreat from the global responsibility considered as a pedagogical mistake if a student fails the expectations? In this regard, life traditions, gained by previous generations are ruined and the psychology of teaching profession does not allow a teacher live according to strict rules.

Peculiarities of teaching profession are one of the most relevant issues both in pedagogy and psychology. Many scientists believe (N. Aminov [1], N. Kuzmina [6], A. Markova [7], V. Semytchenko [12]) that teaching activities are a tool of manifestation of sociocultural experience for the future generations aimed at preparing them for life according to the society's rules.

The characteristics of teaching activities structure in the light of different approaches indicate the content, form, means of teaching profession, conditions and opportunities of its realization, and are associated with dynamic parameters and its specificity [3]. There are several approaches to the understanding of the structure of teaching activities: system approach (N. Kuzmina [6]), reflexive (I. Ziaziun [10]), technological (projective) approach (H. Shchedrovetskyi [13]), activity (A. Markova [7]), synergetic (Vozniuk [2]), etc.

The paper aims to explore psychological peculiarities of teaching profession, namely to analyze the results of the carried out empirical research on the psychological 
characteristics and specificity of teaching profession in terms of a developed theoretical model of exploring the features of teaching activities.

\section{Research Methods}

The study involved 205 teachers of different educational institutions of Kremenchuh, Poltava region.

In terms of the carried out theoretical research we have distinguished the following components of teaching activities: motivational, emotional and axiological, as well as operational (activity).

Let us reveal the essence of the components of teaching activities in terms of the developed structural and dynamic model of the impact of pedagogical stereotypes on teachers' work.

The motivational component is based on personal needs which are realized in the work, providing its efficiency, positive attitude towards it, desire for selfrealization and is closely connected with the level of subjective control.

The emotional and axiological component involves value orientations towards oneself and the environment, humanistic focus, and is characterized by the impact of emotions and feelings on the teaching process, is manifested in a form of stable emotional and regulative reactions.

The operational (activity) component involves the development of communication skills, the sum of teacher's knowledge, its manifestation in different ways and styles, as well as teaching methods.

According to this structure we are going to reveal the procedural character and psychological peculiarities of teaching profession.

It is a common knowledge that the level of spiritual well-being of a highly-competitive teacher depends on the following factors: satisfaction with work, psychological climate in a team, conditions of work and professional success. It is in the educational process where the unity of the following significant professional qualities works: motivation to work, values, psycho-emotional state, self-esteem, teaching style [10].

In order to study the peculiarities of teaching profession and reveal the essence of its procedural component according to the parameters associated with professional competence and efficient work we used Teacher's Psychological Profile Method by H. Rezapkina and Z. Rezapkina [10], which according to the methodical map of our empirical research correspond to the motivational, emotional and axiological, as well as operational (activity) components.

We also used Personality Socio-Communication Competence Inventory for studying the peculiarities of teaching profession more profoundly according to the operational (activity) criterion.

In order to examine the efficiency of the operational (activity) component of teaching activities and to reveal individual differences in teaching activities regulation by teachers we applied The Teaching Style Efficiency Scale by M. Aminov and N. Shelikhova.
In order to study the gender- and experience-related peculiarities we applied Mann-Whitney $U$ test for independent samples.

\section{Research Results}

The research outcomes show that most of the teachers $(65.9 \%)$ have highly developed motivational resource, they are satisfied with the working conditions and are interested in their occupation. We have revealed that $21 \%$ of the respondents are not quite motivated to work (according to the scale "insufficient satisfaction with work"), and $23 \%$ of the teachers have problems with professional adaptation (according to the scale "dissatisfaction with work"). Due to the fact they not get feedback they are full of internal conflicts. According to Teacher's Psychological Profile Method [10], there is positive correlation between the level of teacher's subjective control and the level of satisfaction with work. It should be noted that the indicators of the respondents with the low level of subjective control is $13.7 \%$. Such teachers are prone to emotional burnout, they avoid responsibility, as distinct from those whose subjective control is developed in a proper way (the indicators according to the scales "high/medium levels of subjective control" are $40 \%$ and $46.3 \%$ respectively).

Based on analysis we can admit that $59.5 \%$ of the respondents have democratic relations with their students, they are focused on collaboration. The authoritarian style, proneness to moralize is peculiar for $23.4 \%$ of the respondents. $9.5 \%$ and $10.2 \%$ of the respondents have liberal and mixed teaching styles respectively. The teachers with liberal style stimulate their students', parents' and colleagues' initiative. The pedagogues with the mixed style show their unique teaching pattern. It should be noted that any style can be adequate under certain conditions, and the same can be assumed concerning their efficiency.

$47.3 \%$ of the respondents consider themselves to be highly-qualified professionals and have positive selfesteem. Unstable self-esteem which can be changed depending on a situation is peculiar for $30.2 \%$ of the respondents. It should be marked that $21.5 \%$ of the teachers have mixed type of teaching style, and their self-esteem is considered to be spontaneous, which is indicative of its parceling.

Most of the respondents $(33.7 \%)$ are focused on themselves, their own interests and needs (according to "self-concentration" scale); $25.9 \%$ are positively focused on other people (according to "humanistic focus" scale); and $16.6 \%$ are dependent on the relations with their colleagues. Besides, $24 \%$ of the teachers do not have clear value orientations in their occupation.

It is not surprising that under conditions of social instability, emotional stress teachers' psycho-emotional characteristics are negatively affected; and $56 \%$ of the respondents have unfavorable emotional state.

Only $27.3 \%$ of the teachers possess emotional stability and are self-confident; $16.6 \%$ have contradictions in emotional sphere. 
It is clear that the core of teaching activities is didactic communication (operational (activity) component) as a systemic management of communication in the teaching process. A teacher copes with a lot of constantly arising communication tasks, regulates the communication process, manages students' participation in it. The didactic structure of the lesson should be full of emotional communication characteristics [5, p. 37], which correlated with social peculiarities of a personality [1], is a main aspect of teacher's work as it includes the ability to make adequate decisions in any social situations and understand other people's emotional states; it involves the identification, empathy, social reflection skills.

In order to examine the teaching profession more profoundly through the operational (activity) criterion we used Personality Socio-Communication Competence Inventory [9].

In general, most of the respondents have the high potential of communication skills (according to "communication clumsiness" scale $77 \%$ of the teachers have the low indicators). $77 \%$ of the surveyed are able to confront different difficulties and negative factors, can adequately perceive other people's behavior (as they have low indicators according to "frustration intolerance" scale). Though $31.7 \%$ of the respondents according to "excessive desire for conformity" scale have troubles with forming their own ideas and thoughts, they are dependent on other people. These teachers feel anxious if their opinion does not correspond with other's ideas as they consider other people's thoughts to be correct and decisive.
$23.9 \%$ of the teachers have low intolerance to uncertainty. This phenomenon is based on the idea that uncertainty and unpredictability of events are considered as a pathology which can be cured.

$17.6 \%$ of the respondents are concerned about their social status and the desire to avoid failures; and emotionally negative events are not the main motives for $75.1 \%$ of the pedagogues.

Summarizing it should be emphasized that most of the respondents have the high potential of communication skills which are a significant criterion of operational (activity component) of professional activity in general. Almost one third of the teachers are characterized by the feeling of emotional comfort due to the decisive team idea which is a basis of pedagogical stereotypes formation, it affects the alternatives of personal self-development.

That is why in order to study the efficiency of the operational (activity) component of teaching activities and to determine individual differences in teaching activities regulation by pedagogues we used The Teaching Style Efficiency Scale by M. Aminov and N. Shelikhova. Using normal law of distribution $[2 ; 6]$ for the "asymmetry scale" (which shows the advantages of inefficient methods of stimulation (control) over the efficient ones (development) and is a criterion of pedagogical excellence; and acts like a level of balance between the style of stimulating students by their teachers by means of didactic communication) we have determined the number of the respondents with the low, medium and high levels which according to the didactic components are focused on the result or the development (table 1).

Correspondence of test scores to the levels of the teachers' development levels

Table 1. according to The Teaching Style Efficiency Scale by M. Aminov and N. Shelikhova

\begin{tabular}{|c|c|c|c|}
\hline \multirow{2}{*}{ Scale } & \multicolumn{3}{|c|}{ Levels } \\
\cline { 2 - 4 } & $\begin{array}{c}\text { Low } \\
(\mathrm{n}=37)\end{array}$ & $\begin{array}{c}\text { Medium } \\
(\mathrm{n}=124)\end{array}$ & $\begin{array}{c}\text { High } \\
(\mathrm{n}=44)\end{array}$ \\
\hline Criterion of pedagogical excellence & $(-2,83)-(-0,23)$ & $(-0,22)-0,78$ & $0,79-2,25$ \\
\hline
\end{tabular}

The respondents with the low level of pedagogical excellence are characterized by negative asymmetry of the advantage of inefficient methods of stimulation (control) over the efficient ones, the tendencies of controlling communication style focused on the result.

On the contrary, the primacy of the efficient methods of didactic stimulation over the inefficient ones, which is manifested in the tendency to "supportive communication style" focused on the development, is peculiar for the group with the high level of pedagogical excellence (facilitation).

The author of the technique M. Aminov [1] notes that the instrumental abilities are of crucial importance in the teaching style focused on the development, as they are based on the special emotional resource of preventing emotional burnout at the level of the nervous system. The successful teaching activities focused on the result are provided by terminal abilities. They affect the professional style, act as a criterion of not only specialization, but also pedagogical excellence [1, p. 26-28].

Thus, we distinguish the following groups of teachers: the first one (the high level) - the group of facilitating style - is focused on the development; the second one (the medium level) - the differentiation-focused group (they have no clear focus), and the third one - the controlling group - is focused on the result (Table 2). 
Table 2.

Qualitative and quantitative allocation of the respondents according to the level and focused of the operational (activity) component

\begin{tabular}{|c|c|c|c|}
\hline Name of the group & \multicolumn{2}{|c|}{$\begin{array}{c}\text { Number of the } \\
\text { respondents }\end{array}$} & \multicolumn{1}{|c|}{ Characteristics of teachers } \\
\cline { 2 - 3 } & $(\mathrm{n})$ & $(\%)$ & \\
\hline $\begin{array}{c}\text { Facilitative } \\
\text { (high level) }\end{array}$ & 44 & 21,5 & $\begin{array}{c}\text { The structure of psychological professional skills involves instrumen- } \\
\text { tal abilities; the teachers possess supportive style of pedagogical } \\
\text { communication; are focused on the development }\end{array}$ \\
\hline $\begin{array}{c}\text { Differentiation-focused } \\
\text { (medium level) }\end{array}$ & 124 & 60,5 & $\begin{array}{c}\text { General and special abilities are dominant in the structure of psycho- } \\
\text { logical professional skills; the teachers are situation-focused }\end{array}$ \\
\hline $\begin{array}{c}\text { Controlling } \\
\text { (low level) }\end{array}$ & 37 & 18 & $\begin{array}{c}\text { The structure of psychological professional skills is based on terminal } \\
\text { abilities, the controlling style of pedagogical communication is pre- } \\
\text { dominant; the teachers are focused on the result }\end{array}$ \\
\hline
\end{tabular}

According to Table 2, there are $18 \%$ of the respondents with the low level of pedagogical mastery, $60.5 \%$ with the medium level, and $21 \%$ - with the high level. Most of the teachers have differential profiles. General and special (terminal and instrumental) abilities are predominant in them. In our opinion, such pedagogues are situation-focused and it provides the effectiveness of their work.

The further research work presupposes the comparison analysis of internal ties in the structure of teaching profession of different groups of teachers: facilitative which corresponds to the high level of teaching style balance; differentiation-focused - medium, and controlling - low. We use T-criterion of independent samples for the analysis.

Thus, the group of the teachers with facilitating style is characterized by expressed humanistic focus $(3.95>3.27 ; \mathrm{p}=0.039)$ and greater satisfaction with work (6.82>5.86; $\mathrm{p}=0.011)$ as compared with the differentiation-focused teachers.

Compared to facilitators, the respondents of the differentiation-focused group are more dependent on other people's opinion and evaluation ("focus of colleagues" scale 2.53>1.95; $\mathrm{p}=0.032$ ) and manifest lower interest in their work, have attributes of demotivation, complicated professional self-realization ("dissatisfaction with work" scale $0.73>0.41 ; p=0.017$ ). These people often have liberal attitude towards their students ("liberal style" scale $1.88>1.30 ; \mathrm{p}=0.002$ ), express greater discontent with working conditions ("dissatisfaction with work" scale $0.73>0.35 ; p=0.001$ ) as compared to the controlling type.

Significant differences in the characteristics of selfimage of the teachers belonging to the group of facilitative and controlling types (according to "positive selfperception" scale) "facilitators" have the highest indicators: $5.07>4.16 ; \mathrm{p}=0.030)$. The teachers belonging to the group of controlling style are more dependent on their colleagues' opinions (average scores according to "focus on the colleagues" scale: $2.59>1.95 ; \mathrm{p}=0.023$ ) as compared to those who direct didactic communication in the sphere of the development (the group of facilitative style), they more often express their discontent with work (3.68>2.77; $\mathrm{p}=0.045)$.
Therefore, the relations of teachers of facilitative style with their students are based on humanistic grounds, which is manifested in the high level of their spiritual well-being and satisfaction with work.

The teachers belonging to the differentiation-focused group more often manifest liberal characteristics towards their students, they have problems of emotional and motivation spheres, as well as attributes of complicated professional self-fulfillment.

The teachers of the controlling style are dependent on their colleagues' opinions and have insufficient professional motivation.

In order to study the gender- and experience-related peculiarities we applied Mann-Whitney $U$ test for independent samples.

Considering the fact that only 23 young teachers participated in our survey, using random sampling method we distinguished 3 groups of the respondents including 23 persons each: the $1^{\text {st }}$ group - having working experience up to 5 years, the $2^{\text {nd }}$ one - from 5 to 15 years, the $3^{\text {rd }}$ group - more than 15 years. The representatives of the $1^{\text {st }}$ subgroup have less ability for supporting communication style and focus on the development $(19.22<27.78$; $\mathrm{p}=0.030$ ) as compared to the $3^{\text {rd }}$ group. We have not found any significant differences in the styles of didactic communication between the teachers of the $1^{\text {st }}$ and $2^{\text {nd }}$ groups, as well as between the $2^{\text {nd }}$ and $3^{\text {rd }}$ ones.

Gender differences in the characteristics of inefficient style $(16.90<26.10 ; \mathrm{p}=0.015)$ indicate higher maturity of the facilitative style in female teachers as compared to the controlling one, which is more expressive in male pedagogues.

\section{Conclusion}

Thus, according to the research outcomes, we distinguish the following psychological peculiarities of teaching profession: a) motivational component: the desire to avoid failures and events which cause negative emotions is not the leading motive of the teachers; most of the pedagogues reflect the level of professional success in terms of satisfaction with work and its conditions, manifest interest in the process and results of professional activities, are satisfied with their own skills, personal qualities and place in the society; b) emotional and axiological 
component: most teachers face emotional overloads which are manifested in the instability of their emotional states; c) operational (activity) component: most of the respondents possess highly developed communication

\section{REFERENCES}

1. Aminov, N. A. (1997). Diagnostika pedagogicheskikh sposobnostei [Diagnostics of pedagogical skills]. M. R. Hynzburh (Ed.). Moscow: Yn-t prakt. psikhologii. Voronezh: MODЭK [in Russian].

2. Vozniuk, O. V. (2009). Rozvytok vitchyznianoi pedahohichnoi dumky: synerhetychnyi pidkhid : monohrafiia [Development of domestic pedagogical thought: synergetic approach: monograph]. P. Yu. Saukh (Ed.). Zhytomyr : Vyd-vo ZhDU im. I. Franka [in Ukrainian].

3. Hodfrua, Zh. (2004). Chto takoe psykholohyia: v 2-kh $t$. [What is psychology? In two volumes]. $3^{\text {rd }}$ ed. rev. Vol. 2. Moscow: Mir [in Russian].

4. Davydova, O. V. (2015.) Spetsyfika pedahohichnoi diialnosti vchytelia ta osoblyvosti yii rozvytku [Specificity of teaching activities and peculiarities of its development]. Visnyk pisliadyplomnoi osvity : zb. nauk. pr. Bulletin of post-graduate education of NAES of Ukraine, 15, 200-214. Kyiv : ATOPOL HRUP [I Ukrainian].

5. Kan-Kalyk, V. A. (1987). Uchytelyu o pedagogicheskom obshchenii [For a teacher about pedagogical communication]. Moscow: Prosveshchenye [in Russian].

6. Kuzmyna, N. V. (1984). Pedagogicheskoe masterstvo uchitelya kak faktor razvitiya sposobnostei uchashchykhsya [Teaching excellence as a factor of students' abilities development]. Voprosy psikhologii - Issues of psychology, 1, 20-26 [in Russian].

7. Markova, A. K. (1993). Psikhologiya truda uchitelya: kn. dlya uchitelya [Psychology of teaching

\section{ЛІТЕРАТУРА}

1. Аминов Н. А. Диагностика педагогических способностей / Н.А. Аминов ; под общ. ред. М. Р. Гинзбурга. - М. : Ин-т практ. психологии. Воронеж : МОДЭК, 1997. - 80 с.

2. Вознюк О. В. Розвиток вітчизняної педагогічної думки: синергетичний підхід : монографія / О. В. Вознюк ; за ред. проф. П. Ю. Сауха. - Житомир : Вид-во ЖДУ ім. І. Франка, 2009. - 184 с.

3. Годфруа Ж. Что такое психология: в 2-х т. / Ж. Годфруа. - Изд. 3-е, стерео. ; пер. с фр. - М. : Мир, 2004. - Т. 2. - 376 с.

4. Давидова О. В. Специфіка педагогічної діяльності вчителя та особливості їі розвитку / О. В. Давидова // Вісник післядипломної освіти : зб. наук. пр. ; НАПН України, УН-т менедж. освіти ; редкол. : О. Л. Ануфрієва [та ін]; голов. ред. В. В. Олійник. - Київ : АТОПОЛ ГРУП, 2015. Вип. 15(28). - С. 200-214.

5. Кан-Калик В. А. Учителю о педагогическом общении / В. А. Кан-Калик. - М. : Просвещение, 1987. $-190 \mathrm{c}$. skills, they are able to cope with problems and challenges, as a rule use democratic teaching style; gender characteristics and work experience determine the change in teachers' didactic communication.

profession: book for teachers]. Moscow: Prosveshchenye [in Russian].

8. Nasledov, A. D. (2004). Matematicheskie metody v psikhologii: ucheb. posobye [Mathematical methods in psychology: textbook]. Saint Petersburg: Rech [in Russian].

9. Ovcharova, R. V. (2007). Psikhologicheskaya fasilitatsiya raboty shkolnogo uchitelya: ucheb. posobie [Psychological facilitation of school teacher's work: study guide]. Moscow [in Russian].

10. Ziaziun, I. A. (Ed.). (1997). Pedahohichna maisternist: pidruch. [Pedagogical excellence: textbook]. Kyiv: Vyshcha shk. [in Ukrainian].

11. Rezapkyna, H. V. (2009). Psikhologicheskiy portret uchytelya: opyt samodiagnostiki [Psychological profile of a teacher: self-diagnostics experience]. Psikhologiya i shkola - Psychology and school, 1, 64-75 [in Russian].

12. Semychenko, V. A. (2004). Psykholohiia pedahohichnoi diialnosti: navch. posib. [Psychology of teaching: textbook]. Kyiv: Vyshcha shk [in Ukrainian].

13. Shchedrovytskyi, H. P. (1981). Printsipy i obshchaya skhema metodologicheskoy organizatsii sistemno-strukturnykh issledovaniy i razrabotok [Principles and general scheme of methodological organization of system and structural researches]. Systemnye issledovaniya. Metodologicheskie problemy: ezhegodnik - System researches. Methodological issues: annual journal. Moscow: Nauka [in Russian].

6. Кузьмина Н. В. Педагогическое мастерство учителя как фактор развития способностей учащихся / Н. В. Кузьмина // Вопросы психологии. - 1984. - № 1. - C. 20-26.

7. Маркова А. К. Психология труда учителя: кн. для учителя / А. К. Маркова. - М. : Просвещение, 1993. - 192 с

8. Наследов А. Д. Математические методы в психологи: учеб. пособие / А Д. Наследов. - СПб. : Речь, 2004. - 232 с.

9. Овчарова Р. В. Психологическая фасилитация работы школьного учителя: учеб. пособие / Р. В. Овчарова. - М., 2007. - 305 с.

10. Педагогічна майстерність : підруч. / I. А. Зязюн, Л. В. Крамущенко, І. Ф. Кривонос [та ін.] ; за ред. І. А. Зязюна. - Київ : Вища шк., 1997. 349 c.

11. Резапкина Г. В. Психологический портрет учителя: опыт самодиагностики / Г. В Резапкина., 3. В. Резапкина // Психология и школа. - 2009. - №1. - C. 64-75. 
12. Семиченко В. А. Психологія педагогічної діяльності: навч. посіб. В. А. Семиченко. - Київ :

13. Щедровицкий Г. П. Принципы и общая схема организации системноВища шк., 2004. - 335 с. методологической

структурных исследований и разработок / Г. П. Щедровицкий // Системные исследования. Методологические проблемы: ежегодник. - 1981. М. : Наука, 1981. - С. 193-0227.

Оксана Володимирівна Давидова, здобувач Університету менеджменту освіти, Національна академія педагогічних наук України, практичний психолог вищої категорії, Кременчуцький ліцей інформаційних технологій №-30 ім. Н. М. Шевченко, вул. Олега Кошового, 3, м. Кременчук, Украйна

ПСИХОЛОГІЧНІ ОСОБЛИВОСТІ ПРОФЕСІЙНОЇ ПЕДАГОГІЧНОЇ ДІЯЛЬНОСТІ ВЧИТЕЛЯ

У статті висвітлено результати емпіричного дослідження констатувального етапу дослідження психологічних особливостей впливу педагогічних стереотипів на професійну педагогічну діяльність учителя. У межах порівняльного аналізу за допомогою методів математичної статистики: T-критерію та непараметричного Uкритерію Манна-Уітні для незалежних вибірок вирішуються емпіричні питання змісту та розвиненості процесуальної складової професійної педагогічної діяльності вчителя. Розглядається зміст структурних компонентів професійно-педагогічної діяльності в розрізі структурно-динамічної моделі впливу педагогічних стереотипів на професійну діяльність учителя, які включають відповідні критерії та їх показники. Розкрито процесуальний характер професійної педагогічної діяльності вчителя та проаналізовано відмінності в параметрах професійної компетентності вчителів, що пов'язані з ефективним ії здійсненням та комунікативно-дидактичним потенціалом у залежності від різних педагогічних тактик, спрямованих вчителем на ефективну підтримку дидактичної комунікації в ситуаціях навчальної взаємодії. Розглядається структура професійної педагогічної діяльності в різноспрямованих групах учителів за дидактичною спрямованістю (фасилітативній, диференційно-орієнтованій та контролюючій) в залежності від гендерних характеристик та стажу перебування на посаді. Отримані результати дозволили сформувати висновки про те, що у більшості педагогів виявлено ступінь професійного благополуччя. Учителі Опроявляють інтерес до процесу, результатів своєї діяльності та задоволені собою й своїми можливостями, професійними якостями й місцем серед інших людей. Для працюючих педагогів у школі характерні емоційні перевантаження, що проявляються в нестабільності психоемоційних станів. Проте, в учителів високо розвинений комунікативний потенціал, здатність ефективно протистояти різноманітним труднощам у складних педагогічних ситуаціях. Існують статистично значущі зв'язки в параметрах професійної педагогічної діяльності вчителів різнорівневих груп за дидактичною спрямованістю. Гендерні характеристики та стаж перебування на посаді обумовлюють зміни в характеристиках дидактичної комунікації педагогів.

Ключові слова: професійна педагогічна діяльність, підходи до професійної педагогічної діяльності, структура професійної педагогічної діяльності, компоненти професійної педагогічної діяльності, рівні розвитку досліджуваних властивостей, характеристики дидактичної комунікації, розвиток, гендерні характеристики.

Submitted on June, 15, 2017

Reviewed by Doctor of Psychology, prof. P. Lushyn 